Article

\title{
Persistent Listeria monocytogenes Isolates from a Poultry-Processing Facility Form More Biofilm but Do Not Have a Greater Resistance to Disinfectants than Sporadic Strains
}

\author{
Daniel Rodríguez-Campos ${ }^{1,2}$, Cristina Rodríguez-Melcón ${ }^{1,2}$, Carlos Alonso-Calleja ${ }^{1,2}$ and \\ Rosa Capita ${ }^{1,2, *}$ \\ 1 Department of Food Hygiene and Technology, Veterinary Faculty, University of León, E-24071 León, Spain; \\ drodrc01@estudiantes.unileon.es (D.R.-C.); crodm@unileon.es (C.R.-M.); \\ carlos.alonso.calleja@unileon.es (C.A.-C.) \\ 2 Institute of Food Science and Technology, University of León, E-24071 León, Spain \\ * Correspondence: rosa.capita@unileon.es; Tel.: +34-987-291000 (ext. 5633); Fax: +34-987-442070
}

Received: 23 September 2019; Accepted: 27 October 2019; Published: 20 November 2019

\begin{abstract}
Some strains of Listeria monocytogenes can persist in food-processing environments, increasing the likelihood of the contamination of foodstuffs. To identify traits that contribute to bacterial persistence, a selection of persistent and sporadic L. monocytogenes isolates from a poultry-processing facility was investigated for biofilm-forming ability (crystal violet assay). The susceptibility of sessile cells to treatments (five minutes) with sodium hypochlorite having 10\% active chlorine (SHY: 10,000 ppm, 25,000 ppm, and 50,000 ppm) and benzalkonium chloride (BZK: 2500 ppm, 10,000 ppm, and 25,000 ppm) was also studied. All isolates exhibited biofilm formation on polystyrene. Persistent strains showed larger $(p<0.001)$ biofilm formation $\left(\mathrm{OD}_{580}=0.301 \pm 0.097\right)$ than sporadic strains $\left(\mathrm{OD}_{580}=0.188 \pm 0.082\right)$. A greater susceptibility to disinfectants was observed for biofilms of persistent strains than for those of sporadic strains. The application of SHY reduced biofilms only for persistent strains. BZK increased $\mathrm{OD}_{580}$ in persistent strains $(2500 \mathrm{ppm})$ and in sporadic strains (all concentrations). These results indicate that the use of BZK at the concentrations tested could represent a public health risk. Findings in this work suggest a link between persistence and biofilm formation, but do not support a relationship between persistence and the resistance of sessile cells to disinfectants.
\end{abstract}

Keywords: Listeria monocytogenes; persistent strains; sporadic strains; biofilm formation; resistance to disinfectants

\section{Introduction}

Listeriosis is a food-borne disease responsible for 23,000 infections yearly worldwide [1]. Its lethality rate may reach 30\% [2]. In the United States, approximately 1600 cases of severe forms of human listeriosis occur each year (the incidence rate is 0.26 cases per 100,000 population), and about 260 of these die [3]. As a consequence of demographic changes, the country expects an increase in the prevalence of the disease, such that it will reach a figure of 0.32 cases per 100,000 inhabitants in 2030 [4]. Moreover, listeriosis is estimated to cause an annual loss of 8800 disease adjusted life years (DALYs) in the USA, of which the majority are premature deaths [5].

As for the European Union, in 2017 there were 2480 confirmed cases of invasive listeriosis $(0.48$ cases per 100,000 population). The lethality rate was $13.8 \%$ of the 1633 confirmed cases with a known outcome, the highest among all food-borne illnesses [6]. Moreover, over the last ten years, there has 
been, in the European Union, a substantial increase in the number of cases of human listeriosis, which reached 1381 ( 0.30 cases per 100,000 population) in 2008 [7]. Those suffering the infection most often and most severely are what are termed at-risk groups, such as the young, the old, the pregnant, and the immunocompromised [2].

Twenty species of Listeria have been described [8], but just three of them are pathogenic. Most cases of human listeriosis are caused by Listeria monocytogenes, although on rare occasions infections by Listeria ivanovii and Listeria seeligeri have been recorded [9]. With regard to L. monocytogenes, a total of 13 serotypes (1/2a, 1/2b, 1/2c, 3a, 3b, 3c, 4a, 4ab, 4b, 4c, 4d, 4e, and 7) have been described, although three of them $(1 / 2 a, 1 / 2 b$, and $4 b)$ are responsible for the great majority of cases of human disease [10].

Persistent $L$. monocytogenes strains have been identified as major post-processing contaminants of foodstuffs, and numerous listeriosis outbreaks have been associated with the occurrence of persistent environmental contamination of processing plants [11]. Bacterial persistence is generally defined as the finding over the long term of genetically indistinguishable strains isolated from the same environment [12].

A relationship between biofilm formation and persistence has been suggested [13]. The sessile living state has been shown to be the preferred form of existence for many bacteria, and it is known that cells in biofilms show greater resistance to environmental challenges, such as desiccation, UV light, or sanitizers, than their planktonic counterparts in suspension [14,15]. This may lead to bacterial persistence in food-processing plants. However, the reasons for persistence remain poorly understood, and there is disagreement regarding the relationship between persistence and the ability to form biofilms [16].

Because long-term presence in food-processing plants poses health concerns and presents a risk factor for the economy, it is crucial to identify causes that encourage the persistence of L. monocytogenes in food-processing facilities. The aim of this research was to determine if there is a link between persistence and biofilm-forming capacity or resistance to disinfectants. To that end, a comparison was made of the biofilm-forming abilities of several persistent and sporadic L. monocytogenes strains isolated from a poultry-processing facility in north-western Spain. Additionally, the effects of different concentrations of sodium hypochlorite and benzalkonium chloride on the biofilms formed by these strains was evaluated.

\section{Results}

\subsection{Capacity of L. monocytogenes to Form Biofilm}

The study included ten L. monocytogenes strains isolated from inert surfaces in a poultry-processing plant. The strains belonged to serotypes $1 / 2 b$ (two strains), $1 / 2 c$ (one strain), $3 b$ (one strain), $4 a$ (one strain), and $4 \mathrm{~b}$ (five strains). Isolates were grouped into three phylogenetic lineages: I (strains $1,3,4,5$, 6, 8, 9, and 10), II (strain 7), and III (strain 2), as shown in Figure 1.

All strains formed biofilms on the polystyrene surface under trial. On the basis of the cut-off $\mathrm{OD}_{580}(\mathrm{ODc})$ of 0.168 , strains were classified as moderate (strain 2, serotype 4a) or weak producers of biofilms (remaining strains).

The average value obtained for $\mathrm{OD}_{580}$ was $0.244 \pm 0.106$, with significant differences $(p<0.05)$ being seen between strains (Table 1). No differences were found in the abilities to form biofilms of the various groups of serotypes. The $\mathrm{OD}_{580}$ of strains of serotypes in group $1 / 2(1,6$, and 7$)$ showed a value of $0.230 \pm 0.099$, whilst the value for strains of serotypes in group 4 (strains $2,3,4,5,9$, and 10 ) was $0.261 \pm 0.107$, and that for the strain of serotype $3 b$ (strain 8 ) was $0.188 \pm 0.107(p>0.05)$. 


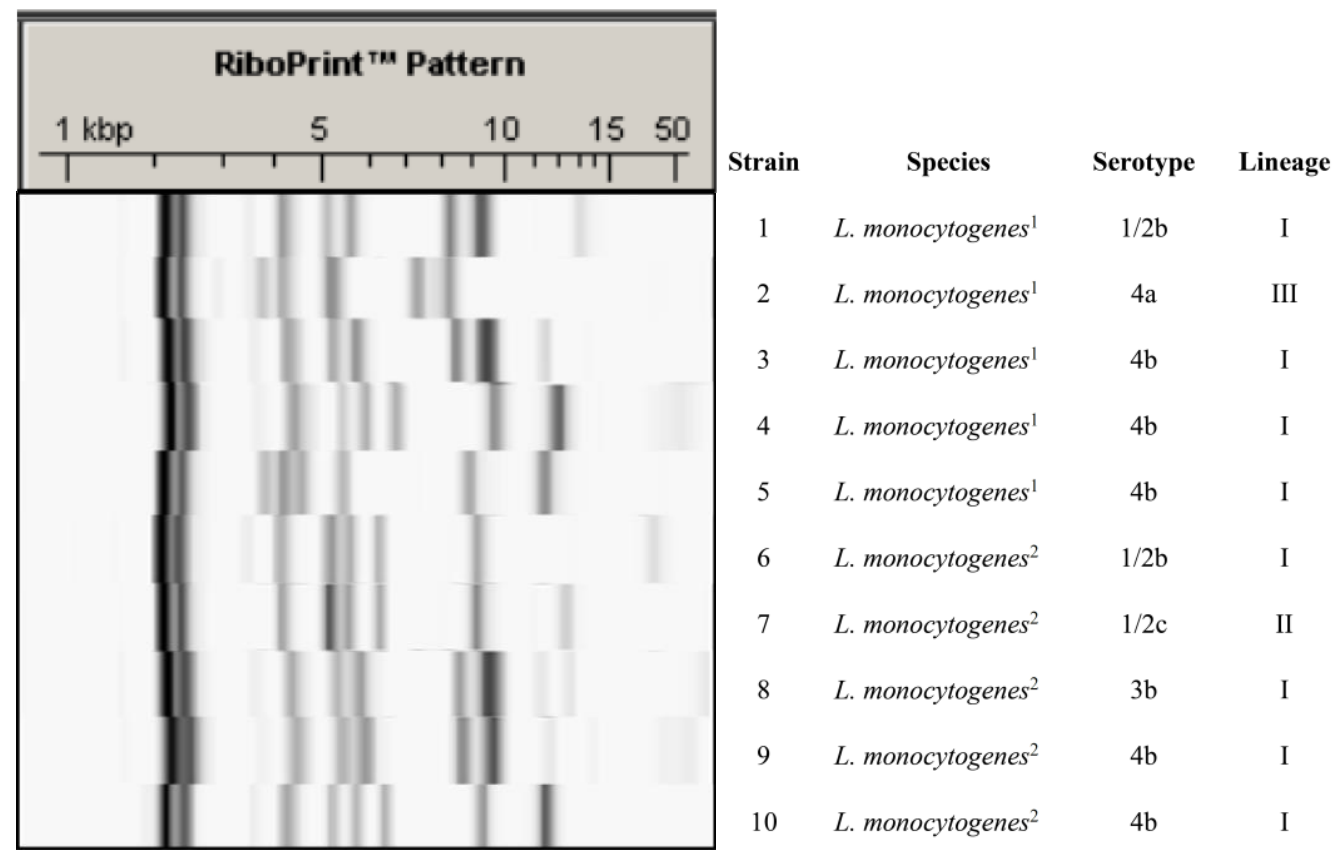

Figure 1. RiboPrint patterns of the 10 strains of Listeria monocytogenes tested. ${ }^{1}$ persistent strains; ${ }^{2}$ sporadic strains. RiboPrint patterns have been cropped from different gels.

Table 1. Biofilm quantities (crystal violet assay; $\mathrm{OD}_{580}$ ) of ten Listeria monocytogenes isolates before (control) and after exposure to sodium hypochlorite or benzalkonium chloride at various concentrations.

\begin{tabular}{|c|c|c|c|c|c|c|c|}
\hline \multirow{3}{*}{$\begin{array}{c}\text { Strain } \\
\text { (Serotype) }\end{array}$} & \multicolumn{7}{|c|}{ Treatment (Five Minutes) } \\
\hline & \multirow{2}{*}{$\begin{array}{c}\text { CONTROL } \\
\text { Without Treatment }\end{array}$} & \multicolumn{3}{|c|}{ Sodium Hypochlorite ( $10 \%$ of Active Chlorine) } & \multicolumn{3}{|c|}{ Benzalkonium Chloride } \\
\hline & & 10,000 ppm & $25,000 \mathrm{ppm}$ & $50,000 \mathrm{ppm}$ & $2500 \mathrm{ppm}$ & $10,000 \mathrm{ppm}$ & $25,000 \mathrm{ppm}$ \\
\hline $1(1 / 2 b)$ & $0.318 \pm 0.053^{\mathrm{abc}}{ }_{\mathrm{cd}}$ & $0.261 \pm 0.1911_{\mathrm{ab}}$ & $0.237 \pm 0.187^{\mathrm{ab}}$ & $0.207 \pm 0.049^{\mathrm{a}}{ }_{\mathrm{a}}$ & $0.493 \pm 0.075_{\mathrm{d}}^{\mathrm{d}_{\mathrm{N}}}$ & $0.436 \pm 0.072^{\mathrm{cd}_{\mathrm{b}}}$ & $0.372 \pm 0.090^{\mathrm{bcd}}{ }_{\mathrm{bc}}$ \\
\hline $3(4 b)$ & $0.244 \pm 0.108^{\mathrm{ab}}{ }_{\mathrm{abcd}}$ & $0.166 \pm 0.044^{\mathrm{ab}}{ }_{\mathrm{a}}^{\mathrm{a}}$ & $0.184 \pm 0.044^{\mathrm{ab}}{ }_{\mathrm{a}}$ & $0.148 \pm 0.061^{\mathrm{a}}{ }_{\mathrm{a}}$ & $0.273 \pm 0.132^{\mathrm{b}}{ }_{\mathrm{a}}$ & $0.258 \pm 0.085^{\mathrm{ab}}{ }_{\mathrm{a}}$ & $0.233 \pm 0.057^{\mathrm{ab}}{ }_{\mathrm{a}}$ \\
\hline $4(4 b)$ & $0.308 \pm 0.103 b_{b c d}$ & $0.229 \pm 0.092 \mathrm{ab}_{\mathrm{a}}$ & $0.225 \pm 0.048 \mathrm{ab}$ & $0.172 \pm 0.054^{a} a_{a}$ & $0.317 \pm 0.119^{b} \mathrm{ab}$ & $0.319 \pm 0.121^{\mathrm{b}} \mathrm{ab}$ & $0.294 \pm 0.092 \mathrm{~b} a b c$ \\
\hline $5(4 b)$ & $0.274 \pm 0.092 \mathrm{bc}_{\mathrm{abcd}}$ & $0.181 \pm 0.087 \mathrm{ab}$ & $0.163 \pm 0.072 \mathrm{ab}_{\mathrm{a}}$ & $0.153 \pm 0.050 a_{a}$ & $0.306 \pm 0.126^{c} \mathrm{c}$ & $0.263 \pm 0.099 \mathrm{abc}_{\mathrm{a}}$ & $0.276 \pm 0.065^{b c} c_{a b}$ \\
\hline $8(3 b)$ & $0.188 \pm 0.107^{\mathrm{ab}}{ }_{\mathrm{a}}$ & $0.211 \pm 0.074^{\mathrm{ab}}{ }_{\mathrm{a}}$ & $0.218 \pm 0.094^{\mathrm{ab}}{ }_{\mathrm{a}}$ & $0.141 \pm 0.046^{\mathrm{a}}{ }_{\mathrm{a}}$ & $0.347 \pm 0.112^{c} \mathrm{abc}$ & $0.284 \pm 0.105^{\mathrm{bc}}{ }_{\mathrm{a}}$ & $0.257 \pm 0.078^{a b c}{ }_{a}^{c}$ \\
\hline $9(4 b)$ & $0.176 \pm 0.069^{a}{ }_{a}$ & $0.188 \pm 0.079^{a_{a}}$ & $0.157 \pm 0.045^{\mathrm{a}} \mathrm{a}$ & $0.186 \pm 0.077^{a_{a}}$ & $0.288 \pm 0.141^{\mathrm{a}}{ }_{\mathrm{a}}$ & $0.229 \pm 0.150 \mathrm{a}_{\mathrm{a}}$ & $0.231 \pm 0.119 \mathrm{a}_{\mathrm{a}}$ \\
\hline $10(4 b)$ & $0.205 \pm 0.072^{a} a b c$ & $0.181 \pm 0.060^{a} a_{a}$ & $0.187 \pm 0.083^{a}{ }_{a}$ & $0.150 \pm 0.025^{a} a_{a}$ & $0.343 \pm 0.134_{\mathrm{abc}}^{\mathrm{b}}$ & $0.266 \pm 0.134^{a b}{ }_{a}$ & $0.232 \pm 0.081 \mathrm{ab}_{\mathrm{a}}$ \\
\hline
\end{tabular}

By lineages, the $\mathrm{OD}_{580}$ of the strain in lineage III, at $0.361 \pm 0.108$, was a higher figure $(p<0.05)$ than the values observed for strains in lineages I $(0.238 \pm 0.096)$ and II $(0.178 \pm 0.104)$. When strains were grouped by persistence, values for $\mathrm{OD}_{580}$ of $0.301 \pm 0.097$ were observed for persistent strains, and of $0.188 \pm 0.082$ for sporadic strains $(p<0.001)$.

\subsection{The Effect of Disinfectants on Biofilms}

Figure 2 shows the values for $\mathrm{OD}_{580}$ averaged over ten strains that were found for untreated biofilms and for those treated with varying concentrations of SHY and BZK. Treatment with SHY reduced $(p<0.05)$ the amount of biofilm at all three concentrations assayed $(10,000 \mathrm{ppm}, 25,000 \mathrm{ppm}$, and 50,000 ppm), even if no major differences were observed relative to untreated biofilms. With regard to BZK, treatment with $25,000 \mathrm{ppm}$ did not modify $\mathrm{OD}_{580}$ of biofilms $(p>0.05)$ relative to untreated biofilms. It must be noted that higher $(p<0.05)$ values for $\mathrm{OD}_{580}$ were observed for biofilms exposed to $2500 \mathrm{ppm}$ and 10,000 ppm of BZK than for untreated biofilms. 


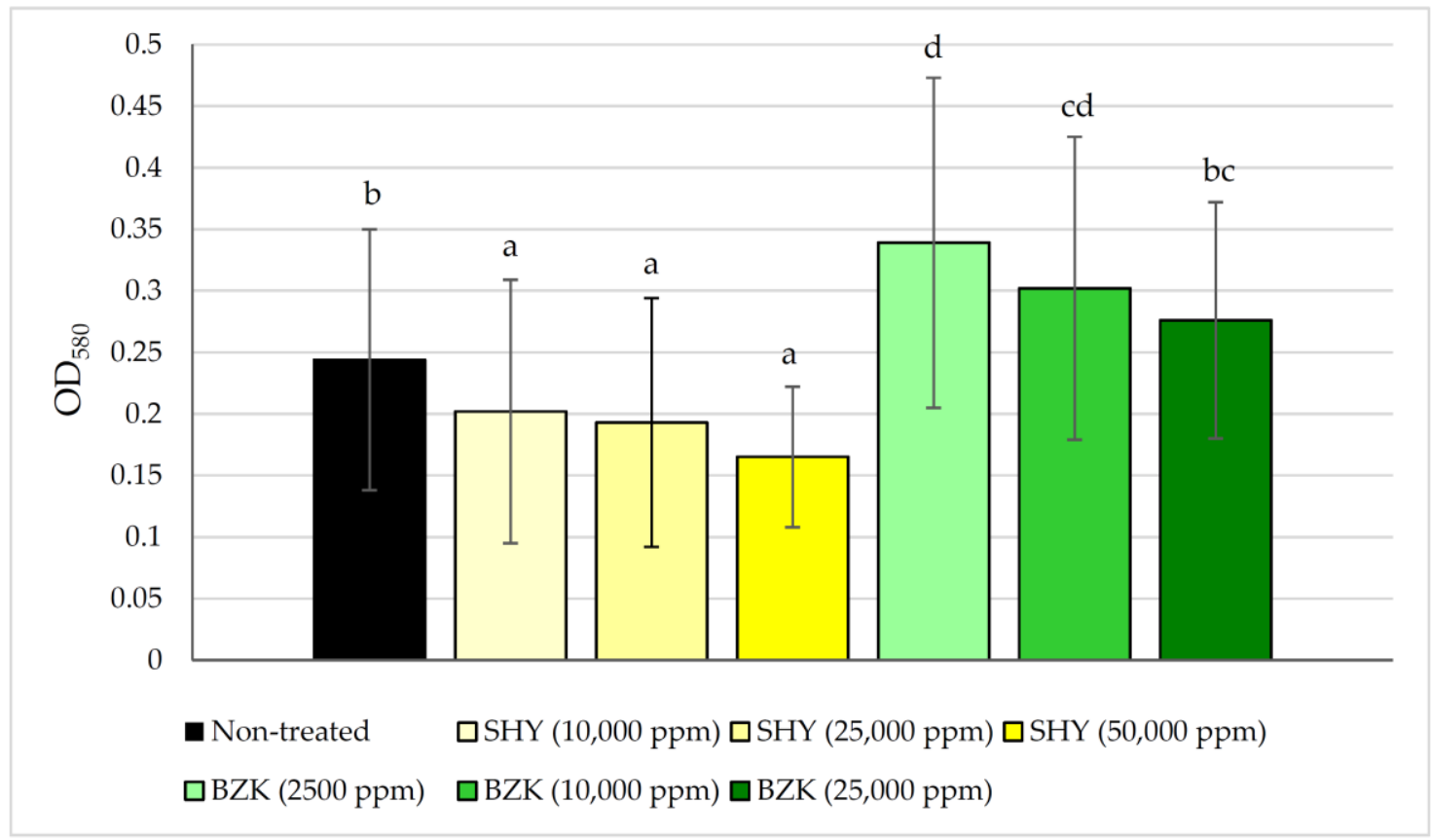

Figure 2. Biofilm formation by Listeria monocytogenes (average values for ten Listeria monocytogenes strains are shown) before and after treatment for five minutes with various concentrations of sodium hypochlorite (SHY) or benzalkonium chloride (BZK). Average values with no letters in common are significantly different $(p<0.05)$.

After treatment with SHY (10,000 ppm, 25,000 ppm or 50,000 ppm) no differences were observed between the $\mathrm{OD}_{580}$ of the various strains (Table 1). However, treatment with BZK (2500 ppm, 10,000 ppm and 25,000 ppm) caused considerable differences among the $\mathrm{OD}_{580}$ figures for different strains. Values were recorded that ran from $0.271 \pm 0.131$ to $0.493 \pm 0.075$ (treatment with BZK at $2500 \mathrm{ppm}$ ), from $0.229 \pm 0.150$ to $0.444 \pm 0.106$ (treatment with BZK at 10,000 ppm), and from $0.226 \pm 0.095$ to 0.388 \pm 0.087 (treatment with BZK at 25,000 ppm).

Table 2 gives the figures for $\mathrm{OD}_{580}$ of persistent and sporadic strains under all the conditions tested. Biofilms formed by persistent strains were more susceptible to disinfectants than those produced by sporadic strains. Thus, SHY reduced the biomass only of those biofilms formed by persistent strains, having no effect on sporadic strains. Treatment with BZK either increased (at $2500 \mathrm{ppm}$ ) or left unchanged (at 10,000 ppm and 25,000 ppm) the biofilms made by persistent strains. In the case of sporadic strains, all three concentrations of BZK increased the biomass of biofilms.

Table 2. Biofilm quantities (crystal violet assay; $\mathrm{OD}_{580}$ ) of five persistent and five sporadic Listeria monocytogenes isolates before (control) and after exposure to sodium hypochlorite or benzalkonium chloride at different concentrations.

\begin{tabular}{|c|c|c|c|c|c|c|c|}
\hline \multirow{3}{*}{$\begin{array}{l}\text { Group of } \\
\text { Strains }\end{array}$} & \multicolumn{7}{|c|}{ Treatment (Five Minutes) } \\
\hline & \multirow{2}{*}{$\begin{array}{c}\text { CONTROL } \\
\text { Without } \\
\text { Treatment }\end{array}$} & \multicolumn{3}{|c|}{ Sodium Hypochlorite ( $10 \%$ of Active Chlorine) } & \multicolumn{3}{|c|}{ Benzalkonium Chloride } \\
\hline & & $10,000 \mathrm{ppm}$ & $25,000 \mathrm{ppm}$ & $50,000 \mathrm{ppm}$ & $2500 \mathrm{ppm}$ & $10,000 \mathrm{ppm}$ & $25,000 \mathrm{ppm}$ \\
\hline $\begin{array}{l}\text { Persistent } \\
\text { Sporadic }\end{array}$ & $\begin{array}{l}0.301 \pm 0.097{ }^{b}{ }_{a} \\
0.188 \pm 0.082{ }^{a}{ }_{b}\end{array}$ & $\begin{array}{l}0.224 \pm 0.1366^{\mathrm{a}}{ }_{\mathrm{a}} \\
0.180 \pm 0.062{ }^{\mathrm{a}}{ }_{\mathrm{a}}\end{array}$ & $\begin{array}{l}0.206 \pm 0.122 \mathrm{a}_{\mathrm{a}} \\
0.180 \pm 0.073 \mathrm{a}_{\mathrm{a}}\end{array}$ & $\begin{array}{l}0.177 \pm 0.059{ }^{\mathrm{a}}{ }_{\mathrm{a}} \\
0.154 \pm 0.052 \mathrm{a}_{\mathrm{a}}\end{array}$ & $\begin{array}{l}0.369 \pm 0.145^{c} c_{a} \\
0.310 \pm 0.117 c_{a}\end{array}$ & $\begin{array}{l}0.344 \pm 0.123 \mathrm{bc}_{\mathrm{a}} \\
0.260 \pm 0.110^{\mathrm{b}}{ }_{\mathrm{b}}\end{array}$ & $\begin{array}{c}0.313 \pm 0.095^{\mathrm{bc}_{\mathrm{a}}} \\
0.239 \pm 0.082 \mathrm{~b}_{\mathrm{b}}\end{array}$ \\
\hline
\end{tabular}

Average values $(n=30)$ in the same row without any letter in common (superscript) are significantly different $(p<0.05)$. Data in the same column without any letter in common (subscript) are significantly different $(p<0.01)$. Five persistent strains of serotypes $1 / 2 b$, $4 a$, and $4 b$, and five sporadic strains of serotypes $1 / 2 b, 1 / 2 c, 3 b$, and $4 b$, were studied. For additional interpretation, see Figure 1. 


\section{Discussion}

\subsection{Capacity of Strains of L. monocytogenes to Form Biofilm}

Some of the serotypes of L. monocytogenes detected in samples taken from surfaces in the chicken-processing plant studied $(1 / 2 b, 1 / 2 c, 3 b, 4 a$, and $4 b)$ are among those most often involved in human listeriosis. Specifically, strains of serotypes $1 / 2 b$ and $4 b$, together with those of serotype $1 / 2 a$, are responsible for approximately $95 \%$ of instances of human illness worldwide [17].

The serotype with the highest percentage of strains was $4 \mathrm{~b}$, to which $50 \%$ of isolates were assigned (60\% of persistent strains and $40 \%$ of sporadic strains). This result is similar to those noted in meat products by other authors [18-21], who observed that between $38.5 \%$ and $50 \%$ of strains isolated from foodstuffs belonged to serotype $4 \mathrm{~b}$. It should be pointed out that this serotype, besides being the type most often implicated in outbreaks of human listeriosis, appears to have greater potential for virulence than others, since it is the variety most often isolated from patients suffering from the most serious forms of the disease [17]. An important outbreak of listeriosis that occurred in Spain during August and September 2019 by chilled pork products, with more of 200 cases of human disease, three deaths, and seven miscarriages, has been linked to L. monocytogenes serotype $4 \mathrm{~b}$ [22,23].

Strains in serotypes $1 / 2 b$, to which $20 \%$ of the isolates tested were ascribed, and $1 / 2 c$, with $10 \%$, have often been detected in food, including meat products $[17,24-29]$. One strain $(10 \%$ of the total) belonged to serotype 3a. This low percentage agrees with the findings of other researchers, who observed a low prevalence of strains of serotype 3a both in foodstuffs [17] and in clinical samples [29-31]. Serotype $4 a$, to which one strain $(10 \%)$ was assigned, is not usually related to food-borne illness, even though it is often isolated from various environmental and food specimens, principally from ruminants and other non-primate mammals [32-34].

L. monocytogenes is divided into four evolutionary lineages (I, II, III, and IV), differing in their distribution and prevalence in the environment $[35,36]$. Strains belonging to lineage I (which includes serotypes $1 / 2 b, 3 b, 3 c$, and $4 b)$ and II $(1 / 2 a, 1 / 2 c$, and $3 a)$ are the most prevalent in human clinical isolates [32-34,37]. Specifically, cases forming part of outbreaks are related to lineage I, whilst sporadic cases are linked to lineage II [34]. Lineages III and IV are uncommon; they include serotypes 4a, $4 c$, and atypical cells of serotype $4 \mathrm{~b}$, and their presence is linked to animals [35,38]. In the work being reported here, lineage I included $80 \%$, and lineage II $10 \%$, of strains. The high percentage of strains in lineage $\mathrm{I}$ is a striking result, because it is unusual for them to appear in food-processing installations [33]. According to Orsi et al. [33], the apparent overrepresentation of lineage II among foods and food-processing environments may be due to an increased ability of strains in this lineage to grow and persist in these habitats.

There are several methodologies for determining biofilm physiology, structure, and composition. Among these, biofilm formation in polystyrene microtiter plates is certainly the most commonly used method $[39,40]$. The fact that all the strains assayed formed biofilms on polystyrene is a result coinciding with previous observations [14,15,41] and the findings of other authors [42,43]. This is a worrying discovery, because biofilms are a cause of contamination of food during processing; thus, representing a danger to public health.

Nonetheless, it must be pointed out that the capacity of strains to form biofilms was low. Nine of the ten isolates were only weak producers of biofilms and only one presented moderate formation of a biofilm. As in the present study, some researchers have also reported a predominance of strains of L. monocytogenes with only weak or moderate abilities to form biofilms, whether the isolates were of clinical or of food origin $[42,44,45]$. Nevertheless, it must be noted that there are discrepancies between studies, and an ability of L. monocytogenes to form moderate to strong biofilms has been reported by other authors [46-48]. The average $\mathrm{OD}_{580}$ observed $(0.244 \pm 0.106)$ coincides with the findings of Kadam et al. [43]. These authors found that after incubation in TSB at $37^{\circ} \mathrm{C}$, the average value for $\mathrm{OD}_{595}$ obtained lay approximately in the range 0.1 to 0.2 . However, the values observed in the present study are lower than those in other research consulted, in which average values for $\mathrm{OD}_{595}$ as high as 
0.55 to 0.93 [49] or 1.14 [50] were observed. The different wavelengths used to measure optical density may be partially responsible for variations between the results of different authors.

As reported in other studies [49-56], there was significant inter-strain variability in biofilm formation. Results in the work being reported here also coincide with the findings of Borucki et al. [49], who observed no significant relationship between the serotype of strains and their ability to form biofilms. Nevertheless, a greater production of biofilms by isolates of group $1 / 2$ relative to other serotypes has frequently been reported $[16,43-45,53,57]$. It should be noted that the limited number of isolates used in the present research prevents strong conclusions from being obtained.

In the present work, it was noted that strains in lineage III formed the largest quantities of biofilm, while no differences were found between lineages I and II with respect to their biofilm-forming abilities. It has been reported that L. monocytogenes serotype $4 \mathrm{a}$ (Lineage III) has a strong ability to form biofilms on polystyrene [58]. Results from this work are also in agreement with findings from Cherifi et al. [59] and from Di Bonaventura et al. [60], who observed no differences between biofilms formed by lineages I and II. However, it must be pointed out that results obtained by different authors are very variable. In some reports $[49,52,54,61,62]$, it was recorded that strains in lineage I produced less biofilm than those in lineage II. Along those lines, some authors have noted that the greater prevalence of strains from lineage II in food-processing contexts might be related to their stronger ability to form biofilms $[36,44,57,61]$. Nevertheless, other studies have showed larger biovolumes among strains from lineage I than among those in lineage II $[51,63]$. The culturing conditions (for instance, temperature or culture medium) and the variability between the strains used in the various studies might be the underlying cause for the divergences in reported data [61].

The persistence of L. monocytogenes in environments where food is processed poses a challenge for public health, not to mention a considerable financial impact. Hence, it is of importance to learn which characteristics favor the persistence of this bacterium in the installations and equipment of food industries. It was with the aim of determining whether a capacity to form biofilms and any resistance to disinfectants might influence the persistence of bacteria, that the present study was carried out on biofilms produced by ten strains of L. monocytogenes (five persistent and five sporadic isolates) before and after exposure to various concentrations of SHY and BZK.

Since more biofilm was produced by persistent isolates than by transient sporadic isolates in the poultry-processing facility investigated, the present study suggests that biofilm formation may have contributed to persistence. Contradictory results have been found by other authors. Some studies showed that persistent strains of L. monocytogenes formed more biofilm than non-persistent strains $[5,13,49,52,54,64,65]$. Others observed no difference between persistent strains as opposed to sporadic strains [44,65-68]. Thus, the association between the ability of L. monocytogenes strains to form biofilms and their persistence in a food-processing plant environment is not clear. Differences in the results of the several studies may be related to inter-strain variability and to variations in methods applied, including sample size, temperature, $\mathrm{pH}$, salt, nutrients, surface material, or growth medium [16]. It should be also noted that background microflora can affect the ability of $L$. monocytogenes to form a biofilm and to persist in in vivo systems [69,70].

\subsection{The Effect of Disinfectants on Biofilms}

The effects of SHY and BZK on biofilms of L. monocytogenes have been studied before [14,15]. However, the concentrations used (between $1750 \mathrm{ppm}$ and $5250 \mathrm{ppm}$ for SHY, and between $1.5 \mathrm{ppm}$ and $19.5 \mathrm{ppm}$ for BZK) were lower than in the present work. Here, the concentrations tested were between 10,000 ppm and 50,000 ppm for SHY, and between 2500 and 25,000 ppm for BZK. Furthermore, in earlier work, no comparisons were made between the biofilm-forming ability of persistent and transient-sporadic L. monocytogenes strains.

The concentrations of disinfectants used in the current research (1000 to $5000 \mathrm{ppm}$ of free chlorine and 2500 to $25,000 \mathrm{ppm}$ of BZK) match the strengths generally used in the food industry, at $800 \mathrm{ppm}$ to $2000 \mathrm{ppm}$ of free chlorine for chlorine-based compounds, such as SHY, and $1000 \mathrm{ppm}$ to $5000 \mathrm{ppm}$ for 
quaternary ammonium compounds, such as BZK [71]. Since the disinfectant concentrations employed in this investigation proved of little effectiveness in eliminating biofilms of L. monocytogenes, especially in the case of BZK, it is suggested that in order to combat sessile cells of this bacterium efficaciously, the concentrations of these biocides normally used should be increased. However, additional research is warranted to substantiate this affirmation.

It was observed that contact between biofilms and BZK increased the amount of biomass (markedly so for concentrations of $2500 \mathrm{ppm}$ ). An enhanced ability to form a biofilm in the presence of BZK has previously been demonstrated for strains of Escherichia coli [72], methicillin-resistant Staphylococcus aureus (MRSA) [73], Salmonella [71,74], and L. monocytogenes [14]. In the present study, the biofilms were exposed to BZK for five minutes and the biocide was then eliminated, although it is probable that residual quantities remained in the wells of the microtiter plate. Between treatment with biocides and staining, 60 to 120 minutes elapsed. It is possible that during this period of time the strains exposed to BZK (in contact with residual amounts of the biocide) may have been able to synthesize biofilms to a greater extent than strains not exposed in this way. The explanation for this greater production of biofilm by the strains exposed to residual doses of BZK may have to do with the adaptational response of the bacteria [71,73]. Another possible explanation for the larger amount of biomass in biofilms observed after contact with BZK is that the disinfectant incremented the quantity of biofilm remaining adherent to the walls of the wells during the fixing and staining process. Nevertheless, further studies would be necessary to confirm these hypotheses. Our results demonstrate that the concentrations of BZK normally used not only are inefficacious in eliminating biofilms of L. monocytogenes, but also imply a risk to consumers when employed. This is because they might lead to the lingering of residual amounts of disinfectant, associated with an increase in the biomass in biofilms. Hence, independently of the causes of the greater quantity of biofilm after exposure to BZK, these results underline the need to review the concentrations of quaternary ammonium compounds used in food premises when the elimination of L. monocytogenes biofilms is intended.

After treatment with SHY, all strains showed similar values for $\mathrm{OD}_{580}$. However, treatment with BZK gave rise to considerable variability between strains with respect of the biomass levels in biofilms. As the effect of BZK is strain-dependent, such results underline the need to screen a wide range of strains in trials intended to assess the effect of this disinfectant on biofilms of L. monocytogenes.

The hypothesis that the persistence of L. monocytogenes is linked to resistance to disinfectants has been investigated in numerous studies [16]. However, an association between resistance to disinfectants and the persistence of the pathogen in different food processing environments has been demonstrated only in a few cases $[11,52,75-78]$. A clear link between persistence and increased disinfectant resistance was not recorded in some other studies [65,68,79-81]. To the best of our knowledge, this is the first report where the greater susceptibility to biocides of the biofilms by L. monocytogenes was observed in the case of the group of persistent strains (Table 2). These findings suggest that resistance to disinfectants in L. monocytogenes sessile cells is strain-dependent, but not associated with persistence. However, it should be noted that these results should be considered with caution because only ten bacterial strains were tested.

\section{Materials and Methods}

\subsection{L. monocytogenes Strains}

Five strains of persistent ribotypes and five transient sporadic strains were selected (Figure 1). Strains were isolated by environmental swabbing from various locations (both product contact and non-product contact surfaces) in a chicken-processing plant in the Province of León in north-western Spain at several times over a period of twelve months. Strains were considered persistent if they were isolated on two occasions at least six months apart and were genetically indistinguishable through ribotyping. Strains were considered sporadic when they were isolated only once over the twelve-month sampling period. 
Strains were stored at $-50{ }^{\circ} \mathrm{C}$ in tryptone soya broth (TSB; Oxoid Ltd., Hampshire, England) supplemented with $20 \%$ ( $\mathrm{vol} / \mathrm{vol})$ of glycerol. To make working cultures, the frozen cells were sub-cultured in TSB at $37^{\circ} \mathrm{C}$ for $24 \mathrm{~h}$. These cultures were then streaked onto tryptone soya agar (TSA; Oxoid) plates and incubated for 18 to $24 \mathrm{~h}$ at $37^{\circ} \mathrm{C}$.

\subsection{Ribotyping and Serotyping}

An automated RiboPrinter®microbial characterization system (DuPont Qualicon, Wilmington, Delaware, USA) was used in accordance with the manufacturer's instructions to perform ribotyping [82]. Lysis of target cells to release cellular DNA, EcoRI digestion of the chromosomal DNA, separation of the resulting fragments by agarose gel electrophoresis, and hybridization with a chemo-luminescent-labelled DNA probe containing the E. coli ribosomal RNA operon were all carried out within eight hours. The numbers, positions, and relative intensities of rRNA operon-specific DNA fragments were estimated automatically by the RiboPrinter analysis software, and a digital record of 256 numerical values for each sample was produced. Linkage distances between patterns were estimated by means of Pearson's correlation coefficient, and isolates were clustered by means of Ward's method, using the Statistica ${ }^{\circledR} 8.0$ software package (StatSoft Inc., Tulsa, Oklahoma, USA). Isolates with a linkage distance equal to or less than 0.05 (1-Pearson's $r$ ) were considered indistinguishable (Figure 1). This threshold was established from a cluster analysis of ribotyping profiles for three $L$. monocytogenes collection strains in three different gels.

Serotyping was performed using the agglutination method performed with a Seiken Listeria antisera kit (Denka Seiken Co., Tokyo, Japan), in accordance with the manufacturer's instructions. Strains were grouped into lineages on the basis of their serotype: lineage I, comprising serotypes $1 / 2 b$, $3 b, 3 c$, and $4 b$, lineage II with serotypes $1 / 2 a, 1 / 2 c$, and $3 a$, and lineages III and IV, comprising serotypes $4 \mathrm{a}$ and $4 \mathrm{c}[1,33]$.

\subsection{Biofilm Determination}

To quantify biofilms, a previously described procedure [83] was followed. Strains cultured on TSA were transferred to TSB and incubated for $18 \mathrm{~h}$ at $37^{\circ} \mathrm{C}$. Once this time had elapsed, the tubes held a concentration of approximately $10^{9} \mathrm{cfu} / \mathrm{mL}$. Four decimal dilutions in TSB were performed to yield concentrations of $10^{5} \mathrm{cfu} / \mathrm{mL}$, which were then used to inoculate the wells of polystyrene microtitre plates (Oy Growth Curves Ab Ltd., Finland). The wells were filled with $225 \mu \mathrm{L}$ of TSB and $25 \mu \mathrm{L}$ of bacterial culture, so that the final concentration in the well was $10^{4} \mathrm{cfu} / \mathrm{mL}$. Negative controls were included, containing $250 \mu \mathrm{L}$ of TSB. The microtiter plates were incubated at $37^{\circ} \mathrm{C}$ for $24 \mathrm{~h}$.

To study biofilms in the absence of disinfectants, the content of the plate was poured off and the wells washed with $300 \mu \mathrm{L}$ of sterilized distilled water. The bacteria that remained attached were fixed by adding $250 \mu \mathrm{L}$ of methanol to each well for 15 minutes. The plates were then emptied, air dried, and stained for five minutes with $250 \mu \mathrm{L}$ per well of an aqueous solution of $0.5 \%$ crystal violet. The wells were then emptied and washed by placing the plate under running water from the tap. The plates were air dried, and then the dye bound to the adherent cells was re-solubilized with $250 \mu \mathrm{L}$ of $33 \%$ acetic acid (Sigma-Aldrich Co., St. Louis, Missouri USA) per well, the substance being allowed to work for one minute. Optical density at $580 \mathrm{~nm}\left(\mathrm{OD}_{580}\right)$ was determined in a Bioscreen C MBR (Oy Growth Curves $\mathrm{Ab}$ ). The micro-well plates were agitated for one minute prior to the measurement of turbidity.

To investigate the effect of disinfectants on biofilms, the strains were incubated at $37^{\circ} \mathrm{C}$ for $24 \mathrm{~h}$ in the wells. These were then emptied and refilled with $250 \mu \mathrm{L}$ of an aqueous solution of the appropriate disinfectant. The substances used were sodium hypochlorite with $10 \%$ free chlorine (SHY; Sigma-Aldrich) and benzalkonium chloride (BZK; Sigma-Aldrich). SHY was used at concentrations of 10,000 ppm (1000 ppm of free chlorine), 25,000 ppm (2500 ppm of free chlorine), and 50,000 ppm (5000 ppm of free chlorine). BZK was used at $2500 \mathrm{ppm}, 10,000 \mathrm{ppm}$, and 25,000 ppm. All the solutions were allowed to work at room temperature for five minutes. Thereafter, the wells were emptied and 
the procedure for staining and measuring $\mathrm{OD}_{580}$ cited above was performed. All experiments were replicated six times on separate days.

Strains were classified as a function of their capacity to form biofilms. The cut-off $\mathrm{OD}_{580}$ (ODc) was defined as three standard deviations above the mean OD of the negative controls. Strains were split into four categories: not biofilm producers, when $\mathrm{OD}_{580} \leq \mathrm{ODc}$; weak biofilm producers, when $\mathrm{ODc}<\mathrm{OD}_{580} \leq(2 \mathrm{ODc})$; moderate biofilm producers, when $(2 \mathrm{ODc})<\mathrm{OD}_{580} \leq$ (4ODc); or strong biofilm producers, when $(4 \mathrm{ODc})<\mathrm{OD}_{580}$ [81].

Control strains that were strong and weak formers of biofilm from the collection of strains of the University of León, Spain, were included in each experiment. Differences in the extent of biofilm formation were examined by analysis of variance (ANOVA) techniques. Mean separations were obtained using Duncan's multiple range test. Significance was determined at the $p<0.05$ level. All data processing in this study was carried out using the Statistica $₫ 8.0$ software package (StatSoft Ltd., Tulsa, Oklahoma, USA).

\section{Conclusions}

All the strains of L. monocytogenes tested were able to form biofilm on polystyrene surfaces, a worrying fact in the context of food safety, in view of the extensive use made of plastics in food-processing installations. The capacity of isolates to form biofilms was strain-dependent, but not associated with the serotype. Furthermore, significant differences in biofilm formation between persistent and non-persistent strains of L. monocytogenes were observed, with persistent strains showing the strongest biofilm-forming ability. Treatment with SHY brought about significant reductions only in the biofilms of persistent strains. BZK increased the amount of biofilm remaining after the disinfection process, more markedly so with sporadic strains. This fact makes plain the potential risk arising from the use of this substance at the concentrations studied. Results in this study suggest that $L$. monocytogenes may persist thanks to its biofilm-forming capacity, which promotes its survival in food-processing facilities. In contrast, sanitizer tolerance does not appear to affect the persistence of strains.

Author Contributions: Conceptualization, C.A.-C. and R.C.; methodology, D.R.-C., C.R.-M., and R.C.; software, R.C.; validation, C.R.-M., C.A.-C., and R.C.; formal analysis, C.A.-C. and R.C.; investigation, D.R.-C., C.R.-M., and R.C.; resources, C.A.-C. and R.C.; data curation, R.C.; writing-original draft preparation, D.R.-C. and R.C.; writing-review and editing, C.A.-C. and R.C.; visualization, C.A.-C.; supervision, C.A.-C.; project administration, R.C.; funding acquisition, R.C. and C.A.-C.

Funding: The authors wish to express their thanks for the grants from the Ministerio de Ciencia, Innovación y Universidades (Spain, RTI2018-098267-R-C33) and from the Junta de Castilla y León (Consejería de Educación, Spain, LE164G18).

Conflicts of Interest: The authors declare no conflicts of interest.

\section{References}

1. Noordhout, C.M.; Devleesschauwer, B.; Angulo, F.J.; Verbeke, G.; Haagsma, J.; Kirk, M.; Havelaar, A.; Speybroeck, N. The global burden of listeriosis: A systematic review and meta-analysis. Lancet Infect. Dis. 2014, 14, 1073-1082. [CrossRef]

2. Lanciotti, R.; Braschi, G.; Patrignani, F.; Gobbetti, M.; De Angelis, M. How Listeria monocytogenes shapes its proteome in response to natural antimicrobial compounds. Front. Microbiol. 2019, 10, 437. [CrossRef]

3. CDC. Listeria (listeriosis). Centers for Disease Control and Prevention. Available online: https://www.cdc. gov/listeria/index.html (accessed on 21 September 2019).

4. Pohl, A.M.; Pouillot, R.; Van Doren, J.M. Changing US population demographics: What does this mean for listeriosis incidence and exposure? Foodborne Pathog. Dis. 2017, 14, 524-530. [CrossRef] [PubMed]

5. Stoller, A.; Stevens, M.J.A.; Stephan, R.; Guldimann, C. Characteristics of Listeria monocytogenes strains persisting in a meat processing facility over a 4-year period. Pathogens 2019, 8, 32. [CrossRef] [PubMed]

6. EFSA; ECDC. The European Union summary report on trends and sources of zoonoses, zoonotic agents and food-borne outbreaks in 2017. EFSA J. 2018, 16, 5500. 
7. EFSA. Trends and sources of zoonoses and zoonotic agents and food-borne outbreaks in the European Union in 2008. EFSA J. 2010, 8, 1496.

8. Leclerq, A.; Moura, A.; Vales, G.; Tessaud-Rita, N.; Aguilhon, C.; Lecuit, M. Listeria thailandensis sp. nov. Int. J. Syst. Evol. Microbiol. 2019, 69, 74-81. [CrossRef]

9. Wagner, M.; McLauchlin, J. Biology in Handbook of Listeria monocytogenes; Dongyou, L., Ed.; CRC Press: Boca Raton, FL, USA, 2008; pp. 3-25.

10. Jamshidi, A.; Zeinali, T. Significance and characteristics of Listeria monocytogenes in poultry products. Int. J. Food Sci. 2019, 2019, 7835253. [CrossRef]

11. Ortiz, S.; López-Alonso, V.; Rodríguez, P.; Martínez-Suárez, J.V. The connection between persistent, disinfectant-resistant Listeria monocytogenes strains from two geographically separate Iberian pork processing plants: Evidence from comparative genome analysis. Appl. Environ. Microbiol. 2016, 82, 308-317. [CrossRef]

12. Schmitz-Esser, S.; Müller, A.; Stessl, B.; Wagner, M. Genomes of sequence type 121 Listeria monocytogenes strains harbor highly conserved plasmids and prophages. Front. Microbiol. 2015, 6, 380. [CrossRef]

13. Nowak, J.; Cruz, C.D.; Tempelaars, M.; Abee, T.; van Vliet, A.M.H.; Fletcher, G.C.; Hedderley, D.; Palmer, J.; Flint, S. Persistent Listeria monocytogenes strains isolated from mussel production facilities form more biofilm but are not linked to specific genetic markers. Int. J. Food Microbiol. 2019, 256, 45-53. [CrossRef] [PubMed]

14. Rodríguez-Melcón, C.; Capita, R.; Rodríguez-Jerez, J.J.; Martínez-Suárez, J.V.; Alonso-Calleja, C. Effect of low doses of disinfectants on the biofilm-forming ability of Listeria monocytogenes. Foodborne Path. Dis. 2019, 16, 262-268. [CrossRef] [PubMed]

15. Rodríguez-Melcón, C.; Riesco-Peláez, F.; García-Fernández, C.; Alonso-Calleja, C.; Capita, R. Susceptibility of Listeria monocytogenes planktonic cultures and biofilms to sodium hypochlorite and benzalkonium chloride. Food Microbiol. 2019, 82, 533-540. [CrossRef] [PubMed]

16. Ferreira, V.; Wiedmann, M.; Teixeira, P.; Stasiewicz, M.J. Listeria monocytogenes persistence in food-associated environments: Epidemiology, strain characteristics, and implications for public health. J. Food Prot. 2014, 77, 150-170. [CrossRef] [PubMed]

17. Shi, W.; Quingping, W.; Jumei, Z.; Moutong, C.; Zéan, Y. Prevalence, antibiotic resistance and genetic diversity of Listeria monocytogenes isolated from retail ready-to-eat foods in China. Food Control 2015, 47, 340-347. [CrossRef]

18. Meloni, D.; Galluzzo, P.; Mureddu, A.; Piras, F.; Griffiths, M.; Mazette, R. Listeria monocytogenes in RTE foods marketed in Italy: Prevalence and automated EcoRI ribotyping of the isolates. Int. J. Food Microbiol. 2009, 129, 166-173. [CrossRef]

19. Vasilev, V.; Japheth, R.; Breuer, R.; Andom, N.; Abraham, R.B.; Yoni, Y.; Valinsky, L.; Agmon, V. A survey of Listeria monocytogenes strains, isolated from ready-to-eat foods in Israel over a period of 10 years, 1998-2007. Food Control 2010, 21, 1179-1181. [CrossRef]

20. Martins, E.A.; Gernmano, P.M.L. Listeria monocytogenes in ready-to-eat, sliced, cooked ham and salami products, marketed in the city of São Paulo, Brazil: Occurrence, quantification, and serotyping. Food Control 2011, 22, 297-302. [CrossRef]

21. Fallah, A.A.; Saei-Dehkordi, S.S.; Rahnama, M.; Tahmasby, H.; Mahzounieh, M. Prevalence and antimicrobial resistance patterns of Listeria species isolated from poultry products marketed in Iran. Food Control 2012, 28, 327-332. [CrossRef]

22. Notification details-2019.2989. Foodborne outbreak caused by Listeria monocytogenes ( $>1.5 \times 10 \mathrm{E} 4$ CFU/g) in chilled pork products from Spain. Available online: https://webgate.ec.europa.eu/rasff-window/portal/ ?event=notificationDetail\&NOTIF_REFERENCE=2019.2989 (accessed on 20 September 2019).

23. Junta de Andalucía. Consejería de Salud y Familias. Available online: https://www.juntadeandalucia.es/ organismos/saludyfamilias/actualidad/noticias/detalle/220344.html (accessed on 20 September 2019).

24. Korsak, D.; Borek, A.; Daniluk, S.; Grabowska, A.; Pappelbaum, K. Antimicrobial susceptibilities of Listeria monocytogenes strains isolated from food and food processing environment in Poland. Int. J. Food Microbiol. 2012, 158, 203-208. [CrossRef]

25. Prencipe, V.A.; Rizzi, V.; Acciari, V.; Iannetti, L.; Giovannini, A.; Serraino, A.; Calderone, D.; Rossi, A.; Morelli, D.; Marino, L.; et al. Listeria monocytogenes prevalence, contamination levels and strains characterization throughout the Parma ham processing chain. Food Control 2012, 25, 150-158. [CrossRef]

26. Kramarenko, T.; Roasto, M.; Meremae, K.; Kuningas, M.; Poltsama, P.; Elias, T. Listeria monocytogenes prevalence and serotype diversity in various foods. Food Control 2013, 30, 24-29. [CrossRef] 
27. Martín, B.; Perich, A.; Gómez, D.; Yangüela, J.; Rodríguez, A.; Garriga, M.; Aymerich, T. Diversity and distribution of Listeria monocytogenes in meat processing plants. Food Microbiol. 2014, 44, 119-127. [CrossRef] [PubMed]

28. Yu, T.; Jiang, X. Prevalence and characterization of Listeria monocytogenes isolated from retail food in Henan, China. Food Control 2014, 37, 228-231. [CrossRef]

29. Ebner, R.; Stephan, R.; Althaus, D.; Brisse, S.; Maury, M.; Tasara, T. Phenotypic and genotypic characteristics of Listeria monocytogenes strains isolated during 2011-2014 from different food matrices in Switzerland. Food Control 2015, 57, 321-326. [CrossRef]

30. Kérouanton, A.; Marault, M.; Petit, L.; Grout, J.; Dao, T.T.; Brisabois, A. Evaluation of a multiplex PCR assay as an alternative method for Listeria monocytogenes serotyping. J. Microbiol. Meth. 2010, 80, 134-137. [CrossRef]

31. Lannetti, L.; Acciari, V.A.; Antoci, S.; Addante, N.; Bardasi, L.; Bilei, S.; Calistri, P.; Cito, F.; Cogoni, P.; D'Aurelio, R.; et al. Listeria monocytogenes in ready-to-eat foods in Italy: Prevalence of contamination at retail and characterization of strains from meat products and cheese. Food Control 2016, 68, 55-61. [CrossRef]

32. Paul, D.; Steele, C.; Donalson, J.R.; Banes, M.M.; Kumar, R.; Bridges, S.M.; Arick, M.; Lawrence, M. Genome comparison of Listeria monocytogenes serotype 4a strain HCC23 with selected lineage I and lineage II $L$. monocytogenes strains and other Listeria strains. Genom. Data 2014, 2, 219-225. [CrossRef]

33. Orsi, R.H.; Den Bakker, H.C.; Wiedmann, M. Listeria monocytogenes lineages: Genomics, evolution, ecology, and phenotypic characteristics. Int. J. Med. Microbiol. 2011, 301, 79-96. [CrossRef]

34. Tsai, Y.-H.L.; Maron, S.B.; McGann, P.; Nightingale, K.K.; Wiedmann, M.; Orsi, R.H. Recombination and positive selection contributed to the evolution of Listeria monocytogenes lineages III and IV, two distinct and well supported uncommon L. monocytogenes lineages. Infect. Gen. Evol. 2011, 11, 1881-1890. [CrossRef]

35. Orsi, R.H.; Bowen, B.M.; Wiedmann, M. Homopolymeric tracts represent a general regulatory mechanism in prokaryotes. BMC Genom. 2010, 11, 15-20. [CrossRef] [PubMed]

36. Valderrama, W.B.; Cutter, C.N. An ecological perspective of Listeria monocytogenes biofilms in food processing facilities. Crit. Rev. Food Sci. Nutr. 2013, 53, 801-817. [CrossRef] [PubMed]

37. Eskhan, A.O.; Abu-Lail, N.I. Cellular and molecular investigations of the adhesion and mechanics of Listeria monocytogenes lineages' I and II environmental and epidemic strains. J. Coll. Interface Sci. 2013, 394, 554-563. [CrossRef] [PubMed]

38. Jeffers, G.T.; Bruce, J.L.; McDonough, P.L.; Scarlett, J.; Boor, K.J.; Wiedmann, M. Comparative genetic characterization of Listeria monocytogenes isolates from human and animal listeriosis cases. Microbiology 2001, 147, 1095-1104. [CrossRef]

39. Azeredo, J.; Azevedo, N.F.; Briandet, R.; Cerca, N.; Coenyed, T.; Costa, A.R.; Desvaux, M.; Di Bonaventura, G.; Hébraud, M.; Jaglic, Z.; et al. Critical review in biofilm methods. Crit. Rev. Microbiol. 2017, 43, 313-351. [CrossRef]

40. González-Machado, C.; Capita, R.; Riesco-Peláez, F.; Alonso-Calleja, C. Visualization and quantification of the cellular and extracellular components of Salmonella Agona biofilms at different stages of development. PLoS ONE 2018, 13, e0200011. [CrossRef]

41. Rodríguez-Melcón, C.; Riesco-Peláez, F.; Carballo, J.; García-Fernández, C.; Capita, R.; Alonso-Calleja, C. Structure and viability of 24- and 72-h-old biofilms formed by four pathogenic bacteria on polystyrene and glass contact surfaces. Food Microbiol. 2018, 76, 513-517. [CrossRef]

42. Rodrigues, L.B.; dos Santos, L.R.; Tagliari, V.Z.; Rizzo, N.N.; Trenhago, G.; de Oliveira, A.P.; Goetz, F.; do Nascimento, V.P. Quantification of biofilm production on polystyrene by Listeria, Escherichia coli and Staphylococcus aureus isolated from a poultry slaughterhouse. Braz. J. Microbiol. 2010, 41, 1082-1085. [CrossRef]

43. Kadam, S.R.; Den Besten, H.M.W.; Dan Der Veen, S.; Zwietering, M.H.; Moezelaar, R.; Abee, T. Diversity assessment of Listeria monocytogenes biofilm formation: Impact of growth condition, serotype and strain origin. Int. J. Food Microbiol. 2013, 165, 259-264. [CrossRef]

44. Harvey, J.; Keenan, K.P.; Gilmour, A. Assessing biofilm formation by Listeria monocytogenes strains. Food Microbiol. 2007, 24, 380-392. [CrossRef]

45. Barbosa, J.; Borges, S.; Camino, R.; Magalhães, R.; Ferreira, V.; Santos, I.; Silva, J.; Almeida, G.; Teixeira, P. Biofilm formation among clinical and food isolates of Listeria monocytogenes. Int. J. Microbiol. 2013, 2013, 524975. [CrossRef] [PubMed] 
46. Chavant, P.; Martinie, B.; Meylheuc, T.; Bellon-Fontaine, M.-N.; Hebraud, M. Listeria monocytogenes LO28: Surface physicochemical properties and ability to form biofilms at different temperatures and growth phases. Appl. Environ. Microbiol. 2002, 68, 728-737. [CrossRef] [PubMed]

47. Torlak, E.; Sert, D. Combined effect of benzalkonium chloride and ultrasound against Listeria monocytogenes biofilm on plastic surface. Lett. Appl. Microbiol. 2013, 57, 220-226. [CrossRef] [PubMed]

48. Guilbaud, M.; Piveteau, P.; Desvaux, M.; Brisse, S.; Briandet, R. Exploring the diversity of Listeria monocytogenes biofilm architecture by high-throughput confocal laser scanning microscopy and the predominance of the honeycomb-like morphotype. Appl. Environ Microbiol. 2015, 81, 1813-1819. [CrossRef] [PubMed]

49. Borucki, M.K.; Peppin, J.D.; White, D.; Loge, F.; Call, D.R. Variation in biofilm formation among strains of Listeria monocytogenes. Appl. Environ. Microbiol. 2003, 69, 7336-7342. [CrossRef] [PubMed]

50. Nilsson, R.E.; Ross, T.; Bowman, J.P. Variability in biofilm production by Listeria monocytogenes correlated to strain origin and growth conditions. Int. J. Food Microbiol. 2011, 150, 14-24. [CrossRef]

51. Djordjevic, D.; Wiedmann, M.; McLandsborough, L.A. Microtiter plate assay for assessment of Listeria monocytogenes biofilm formation. Appl. Environ. Microbiol. 2002, 68, 2950-2958. [CrossRef]

52. Lunden, J.M.; Miettinen, M.K.; Autio, T.J.; Korkeala, H.J. Persistent Listeria monocytogenes strains show enhanced adherence to food contact surface after short contact times. J. Food Prot. 2000, 63, 1204-1207. [CrossRef]

53. Norwood, D.E.; Gilmour, A. Adherence of Listeria monocytogenes strains to stainless steel coupons. J. Appl. Microbiol. 1999, 86, 576-582. [CrossRef]

54. Norwood, D.E.; Gilmour, A. The differential adherence capabilities of two Listeria monocytogenes strains in monoculture and multispecies biofilms as a function of temperature. Lett. Appl. Microbiol. 2001, 33, 320-324. [CrossRef]

55. Nakamura, H.; Takakura, K.-I.; Sone, Y.; Itano, Y.; Nishikawa, Y. Biofilm formation and resistance to benzalkonium chloride in Listeria monocytogenes isolated from a fish processing plant. J. Food Prot. 2013, 76, 1179-1186. [CrossRef] [PubMed]

56. Folsom, J.P.; Siragusa, G.R.; Frank, J.F. Formation of biofilm at different nutrient levels by various genotypes of Listeria monocytogenes. J. Food Prot. 2006, 69, 826-834. [CrossRef] [PubMed]

57. Pan, Y.; Breidt, F.; Gorski, L. Synergistic effects of sodium chloride, glucose, and temperature on biofilm formation by Listeria monocytogenes serotype 1/2a and 4b strains. Appl. Environ. Microbiol. 2010, 76, 1433-1441. [CrossRef] [PubMed]

58. Osman, K.M.; Samir, A.; Abo-Shama, U.H.; Mohamed, E.A.; Orabi, A.; Zolnikov, T. Determination of virulence and antibiotic resistance pattern of biofilm producing Listeria species isolated from retail raw milk. BMC Microbiol. 2016, 16, 263. [CrossRef] [PubMed]

59. Cherifi, T.; Jacques, M.; Quessy, S.; Fravalo, P. Impact of nutrient restriction on the structure of Listeria monocytogenes biofilm grown in a microfluidic system. Front. Microbiol. 2017, 8, 864. [CrossRef]

60. Di Bonaventura, G.; Piccolomini, R.; Paludi, D.; D’Orio, V.; Vergara, A.; Conter, M.; Ianieri, A. Influence of temperature on biofilm formation by Listeria monocytogenes on various food-contact surfaces: Relationship with motility and cell surface hydrophobicity. J. Appl. Microbiol. 2008, 104, 1552-1561. [CrossRef]

61. Combrouse, T.; Sadovskaya, I.; Faille, C.; Kol, O.; Guérardel, Y.; Midelet-Bourdin, G. Quantification of the extracellular matrix of the Listeria monocytogenes biofilms of different phylogenic lineages with optimization of culture conditions. J. Appl. Microbiol. 2013, 114, 1120-1131. [CrossRef]

62. Colagiorgi, A.; Bruini, I.; Di Ciccio, P.A.; Zanardi, E.; Ghidini, S.; Ianeri, A. Listeria monocytogenes biofilms in the wonderland of food industry. Pathogens 2017, 6, 41. [CrossRef]

63. Takahashi, H.; Miya, S.; Igarashi, K.; Suda, T.; Kuramoto, S.; Kimura, B. Biofilm formation ability of Listeria monocytogenes isolates from raw ready-to-eat seafood. J. Food Prot. 2009, 72, 1476-1480. [CrossRef]

64. Smoot, L.M.; Pierson, M.D. Effect of environmental stress on the ability of Listeria monocytogenes Scott A to attach to food contact surfaces. J. Food Prot. 1998, 61, 1293-1298. [CrossRef]

65. Wang, J.; Ray, A.J.; Hammons, S.R.; Oliver, H.F. Persistent and transient Listeria monocytogenes strains from retail deli environments vary in their ability to adhere and form biofilms and rarely have inlA premature stop codons. Foodborne Pathog. Dis. 2015, 12, 151-158. [CrossRef] [PubMed]

66. Doyle, M.P.; Beuchat, L.R.; Montville, T.M. Food Microbiology: Fundamentals and Frontiers; ASM Press: Washington, DC, USA, 1997. 
67. Ochiai, Y.; Yamada, F.; Mochizuki, M.; Takano, T.; Hondo, R.; Ueda, F. Biofilm formation under different temperature conditions by a single genotype of persistent Listeria monocytogenes strains. J. Food Prot. 2014, 77, 133-140. [CrossRef] [PubMed]

68. Costa, A.; Bartolotti, L.; Brito, L.; Civera, T. Biofilm formation and disinfectant susceptibility of persistent and nonpersistent Listeria monocytogenes isolates from Gorgonzola cheese processing plants. Foodborne Pathog. Dis. 2016, 13, 602-609. [CrossRef] [PubMed]

69. Sashara, K.; Zottola, E.A. Biofilm formation by Listeria monocytogenes utilizes a primary colonizing microorganism in flowing systems. J. Food Prot. 1993, 56, 1022-1028. [CrossRef]

70. Carpentier, B.; Chassaing, D. Interactions in biofilms between Listeria monocytogenes and resident microorganisms from food industry premises. Int. J. Food Microbiol. 2004, 97, 111-122. [CrossRef]

71. Capita, R.; Fernández-Pérez, S.; Buzón-Durán, L.; Alonso-Calleja, C. Effect of sodium hypochlorite and benzalkonium chloride on the structural parameters of the biofilms formed by ten Salmonella enterica serotypes. Pathogens 2019, 8, 154. [CrossRef]

72. Capita, R.; Riesco-Peláez, F.; Alonso-Hernando, A.; Alonso-Calleja, C. Exposure of Escherichia coli ATCC 12806 to sublethal concentrations of food-grade biocides influences its ability to form biofilm, resistance to antimicrobials, and ultrastructure. Appl. Environ. Microbiol. 2014, 80, 1268-1280. [CrossRef]

73. Buzón-Durán, L.; Alonso-Calleja, C.; Riesco-Peláez, F.; Capita, R. Effect of sub-inhibitory concentrations of biocides on the architecture and viability of MRSA biofilms. Food Microbiol. 2017, 65, 294-301. [CrossRef]

74. Capita, R.; Buzón-Durán, L.; Riesco-Peláez, F.; Alonso-Calleja, C. Effect of sub-lethal concentrations of biocides on the structural parameters and viability of the biofilms formed by Salmonella Typhimurium. Foodborne Path. Dis. 2017, 14, 350-356. [CrossRef]

75. Aase, B.; Sundheim, G.; Langsrud, S.; Rørvik, L.M. Occurrence of and a posible mechanism for resistance to a quaternary ammonium compound in Listeria monocytogenes. Int. J. Food Microbiol. 2000, 62, 57-63. [CrossRef]

76. Fox, E.M.; Leonard, N.; Jordan, K. Physiological and transcriptional characterization of persistent and non persistent Listeria monocytogenes isolates. Appl. Environ. Microbiol. 2011, 77, 6559-6569. [CrossRef] [PubMed]

77. Martínez-Suárez, J.V.; Ortiz, S.; López-Alonso, V. Potential impact of the resistance to quaternary ammonium disinfectants on the persistence of Listeria monocytogenes in food processing environments. Front. Microbiol. 2016, 7, 638. [CrossRef] [PubMed]

78. Møretrø, T.; Schirmer, B.C.T.; Heir, E.; Fagerlund, A.; Hjemli, P.; Langsrud, S. Tolerance to quaternary ammonium compound disinfectants may enhance growth of Listeria monocytogenes in the food industry. Int. J. Food Microbiol. 2017, 241, 215-224. [CrossRef] [PubMed]

79. Holah, J.T.; Taylor, J.H.; Dawson, D.J.; Hall, K.E. Biocide use in the food industry and the disinfectant resistance of persistent strains of Listeria monocytogenes and Escherichia coli. J. Appl. Microbiol. 2002, 92, 111S-220S. [CrossRef] [PubMed]

80. Kastbjerg, V.G.; Gram, L. Model systems allowing quantification of sensitivity to disinfectants and comparison of disinfectant susceptibility of persistent and presumed nonpersistent Listeria monocytogenes. J. Appl. Microbiol. 2009, 106, 1667-1681. [CrossRef] [PubMed]

81. Heir, E.; Lindstedt, B.A.; Røtterud, O.J.; Vardund, T.; Kapperud, G.; Nesbakken, T. Molecular epidemiology and disinfectant susceptibility of Listeria monocytogenes from meat processing plants and human infections. Int. J. Food Microbiol. 2004, 96, 85-96. [CrossRef]

82. Capita, R.; Alonso-Calleja, C.; Prieto, M. Prevalence of Salmonella enterica serovars and genovars from chicken carcasses in slaughterhouses in Spain. J. Appl. Microbiol. 2007, 103, 1366-1375. [CrossRef]

83. Díez-García, M.; Capita, R.; Alonso-Calleja, C. Influence of serotype on the growth kinetics and the ability to form biofilms of Salmonella isolates from poultry. Food Microbiol. 2012, 31, 173-180. [CrossRef]

(C) 2019 by the authors. Licensee MDPI, Basel, Switzerland. This article is an open access article distributed under the terms and conditions of the Creative Commons Attribution (CC BY) license (http://creativecommons.org/licenses/by/4.0/). 